\title{
PERAN TOKOH MASYARAKAT DALAM MEMBINA TOLERANSI ANTARUMAT BERAGAMA (Studi di Kelurahan Karang Baru Kota Mataram)
}

\author{
${ }^{1}$ Fransiska Dian Andanasari, ${ }^{2} \mathrm{Hj}$. Yuliatin, ${ }^{3} \mathrm{H}$. Dahlan \\ Fakultas Keguruan Ilmu Pendidikan \\ Program Studi Pendidikan Pancasila dan Kewarganegaraan \\ Universitas Mataram \\ Jl. Majapahit No. 62, Gomong, Kec. Selaparang Kota Mataram \\ ${ }^{1}$ fransiskadianandanasari@gmail.com \\ ²yuliunram@yahoo.com \\ ${ }^{3}$ dahlan.01fkip@gmail.com
}

\begin{abstract}
This study aims to find out how the role of community leaders in fostering tolerance between religious communities in KarangBaru Village, Mataram City, as well as knowing other things related to tolerance in society. The type of research used in this study uses qualitative methods, descriptive approaches, and phenomenological theoretical foundations. Data collection techniques using interviews, observation, and documentation. Data analysis techniques by means of data collection, data reduction, data presentation, conclusion, and verification. Techniques to test the validity of the data using triangulation (combined). Thus, researchers can see how community leaders foster tolerance between existing religious communities through the roles that community leaders carry out according to their positions.
\end{abstract}

Keywords: Community Leaders, Tolerance, Religious People.

Abstrak

Penelitian ini bertujuan untuk mengetahui bagaimana peran dari tokoh masyarakat dalam mebina toleransi antarumat beragama yang ada di Kelurahan Karang Baru Kota Mataram, serta mengetahui hal-hal lain yang menyangkut dengan toleransi di masyarakat. Jenis penelitian yang digunakan dalam penelitian ini menggunakan metode kualitatif, pendekatan deskriptif dan landasan teori fenomenologi. Teknik pengumpulan data menggunakan cara wawancara, obsevasi dan dokumentasi. Teknik analisis data dengan cara pengumpulan data, reduksi data, penyajian data, Kesimpulan dan verifikasi. Teknik untuk menguji keabsahan data menggunakan trianggulasi (gabungan). Sehingga, peneliti dapat melihat cara tokoh masyarakat membina toleransi antarumat beragama yang sudah ada melalui peran yang tokoh masyarakat jalankan sesuai dengan kedudukannya.

Kata Kunci:Tokoh Masyarakat, Toleransi, UmatBeragama.

\section{PENDAHULUAN}

\section{LatarBelakang}

Bangsa Indonesia dikenal sebagai bangsa yang pluralistik. Sebagai bangsa yang pluralistik karena merangkum keberagaman agama, etnis, seni, tradisi, budaya, dan cara hidup. Hal ini juga diperkuat dari pernyataan Furnival, yang mengatakan masyarakat majemuk (plural societies) adalah sekelompok masyarakat yang terdiri dari dua atau lebih ragam budaya, suku, dan agama yang hidup sendiri-sendiri di dalam kesatuan negara [1].

Rasa nyaman dan damai di tengah keberagaman tidak terlepas dari peran tokoh masyarakat. Peran (role) merupakan aspek dinamis dari kedudukan (status). Apabila seseorang melakukan hak dan kewajibannya sesuai dengan kedudukannya, maka ia menjalankan suatu peranan[2]. Dalam hal ini peran yang ia jalankan sangat menentukan apa yang diperbuatnya bagi masyarakatnya serta kesempatan-kesempatan yang diberikan oleh masyarakat kepadanya. Peran itu sangat penting, karena dari peran itu orang yang memiliki kedudukan (status) dapat mengatur perilaku seseorang. 
Tokoh masyarakat adalah seseorang yang memiliki kedudukan (status) sosial di masyarakat. Kedudukan (status) sosial di masyarakat ini menjadikan tokoh masyaraka tmemiliki peran (role) yang ia jalankan untuk mengatur perilaku masyarakat. Tokoh masyarakat juga seseorang yang dapat dihormati oleh masyarakatnya karena ia memiliki karakter baik, memiliki kekayaan ilmu pengetahuan maupun kesuksesan dalam menjalankan kehidupannya sehingga ia dapat ditiru oleh masyarakatnya. Yang termaksut tokoh masyarakat yaitu Lurah, Kepala Lingkungan, RT/RW, serta tokoh agama (Kyai, Pedande, ketuadoa dan tokoh yang bergerak dalam bidang keagamaan). Adapun peran yang dijalankan oleh tokoh masyarakat yang ada di Kelurahan Karang Baru, Kota Mataram, yaitu peran sebagai pembimbing dan peran sebagai mediator.

Peran tokoh masyarakat sebagai pembimbing yaitu memberikan bantuan secara terus menerus kepada masyarakat melalui kegiatan keagamaan nantinya masyarakat dapat mengarahkan dirinya, sehingga dapat bertindak wajar sesuai dengan lingkungannya[3]. Selain itu sebagai mediator, tokoh masyarakat dapat menjadi pihak netral yang dapat menengahi apa bila terjadi permasalahan di masyarakat melalui musyawarah[4].

Peran-peran tersebut dapat membina toleransi yang ada di masyarakat Kelurahan Karang Baru Kota Mataram. Toleransi adalah sikap saling menghargai dan menghormati segala aktivitas yang dilakukan oleh pribadi atau kelompok dalam masyarakat yang harus dibina di dalam diri masyarakat sipil (civil society)[5]. Bila tidak ada sikap toleransi tidak menutup kemungkinan akan timbul intoleransi yang mengakibatkan konflik.

Hal ini sesuai dengan yang ada di Kelurahan Karang Baru khususnya Lingkungan Karang Baru Utara dan Lingkungan Karang Baru Selatan. Seperti pada hasil wawancara awal bersama Isaskardiri, pegawai Kantor Kelurahan Karang Baru, pada hari Rabu, 10 Febuari 2021 lalu. Menurut beliau, Secara keseluruhan Kelurahan Karang Baru sangat aman, memiliki toleransi yang cukup antarpemeluk agama, tidak pernah ada percecokan bahkan konflik antarawarga karena persoalan agama. Muskipun dulu pernah ada kerusuhan tahun 2000, tetapi kerusuhan itu merupakan kasus nasional.

Toleransi antarumat beragama yang ada di masyarakat Kelurahan Karang Baru cukup baik. Hal ini dapat dilihat ketika masyarakat merayakan hari raya keagamaan seperti Maulid Nabi Muhammad, Nyepi, dan Natal dari kedualingkungan. Sebagai bentuk wujud toleransi antara pemeluk agama, masyarakat menghargai kelompok masyarakat lain yang sedang mengadakan ibadah di harirayanya dengan tidak membuat keributan, atau mengikut campuri kegiatan keagamaan kelompok masyarakat yang berbeda dengannya. Selain itu ada masyarakat yang datang untuk saling bersilahturahmi (berkunjung) mengucapkan selamat hari raya dan ada juga yang sekedar mengucapkan selamat hari raya bila berpapasan di jalan.

Secara persentase masyarakat Lingkungan Karang Baru Utara dan masyarakat Lingkungan Karang Baru Selatan sangat beragam, masyarakat yang beragama Islam di Lingkungan Karang Baru Selatan berjumlah 1.549 jiwa (100\%), masyarakat Lingkungan Karang Baru Utara yang beragama Hindu berjumlah 1.134 jiwa $(99,8 \%)$, dan masyarakat yang beragama Katolik berjumlah 13 jiwa (0,59\%) (data sensus penduduk Lingkungan Karang Baru Selatan dan Lingkungan Karang Baru Utara 2020). Dilihat dari jumlah persentase pemeluk agama di kedua lingkungan yang beragam terbukti jumlah persentase pemeluk agama Islam dan Hindu hampir sama.

Alasan peneliti menulis judul ini karena keberhasilan peran dari tokoh masyarakat setempat, sehingga peneliti sangat tertarik untuk meneliti bagaimana peran dari tokoh masyarakat di kedualingkungan tersebut. Maka munculah judul Peran Tokoh Masyarakat Dalam MembinaToleransi Antarumat Beragama (Studi di Kelurahan Karang Baru Kota Mataram). Hal 
ini sangat penting sebagai masukan bagi masyarakat agar selalu menjaga toleransi antarumat beragama di Kelurahan Karang Baru.

\section{RumusanMasalah}

Sesuai dengan latar belakang di atas, maka yang menjadi rumusan masalah adalah Bagaimana peran tokoh masyarakat dalam membina toleransi antarumat beragama di Kelurahan Karang Baru, Kota Mataram?

\section{TujuanPenelitian}

Berdasarkan pada rumusan di atas, maka tujuan penelitian ini adalah

Untuk mengetahui bagaimana peran tokoh masyarakat dalam membina toleransi antarumat beragama di Kelurahan Karang Baru, Kota Mataram.

\section{ManfaatPenelitian}

a. Manfaat Bagi Pemerintah

Penelitian ini sangat berguna bagi pemerintah pusat maupun pemerintah daerah, khususnya Pemerintah Provinsi Nusa Tenggara Barat untuk menambah literasi tentang hidup bertoleransi, sehingga pemerintah mampu membuat sebuah peraturan yang nantinya dapat berguna sebagai pedoman untuk melindungi masyarakat dan bagaimana pemerintah mengupayakan kehidupan bermasyarakat yang kondusif di dalam keberagaman agama.

b. Manfaat Bagi Masyarakat

Hasil penelitian ini diharapkan dapat berguna bagi masyarakat, khususnya masyarakat Kelurahan Karang Baru serta masyarakat pada umumnya dalam mengupayakan terbinanya hidup bertoleransi antarumat beragama, menghargai perbedaan yang ada, tidak bersikap eksklusif atau tertutup melainkan inklusif atau bersifat terbuka.

c. Manfaat Bagi Peneliti

Penelitian ini bermanfaat bagi peneliti untuk mengetahui bagaimana cara tokoh masyarakat menjalankan peranannya dalam membina toleransi di masyarakat, serta mengetahui hal-hal penting lainnya guna terbinanya toleransi di masyarakat. Memberikan gambaran bagi peneliti berikutnya untuk melakukan penelitian yang lebih luas atau mendalam. Mendorong peneliti lainnya yang berminat untuk membuat penelitian dengan lokasi penelitian yang sama lewat sudut pandang yang berbeda yang tidak dapat dijangkau oleh peneliti dalam penelitian ini.

\section{KAJIAN PUSTAKA}

\section{TinjauanTentang Peran Tokoh Masyarakat}

a. Pengertian Tokoh Masyarakat

Ahira mendefinisikan bahwa tokoh masyarakat adalah orang yang memiliki pengaruh dan dihormati oleh masyarakat karena kekayaan ilmu pengetahunan maupun kesuksesannya dalam menjalankan kehidupan, serta dapat menjadi contoh teladan bagi masyarakat daerah yang ia pimpin.[6]. Penokohan ini berlangsung sesuai waktu yang ditentukan, tergantung dari tempatnya menjabat.

b. Peran Tokoh Masyarakat

Peran (role) merupakan aspek dinamis kedudukan (status). Apabila seseorang melakukan hak dan kewajibannya sesuai dengan kedudukannya, maka ia menjalankan suatu peranan. Peran yang dijalankan sangat menentukan apa yang diperbuatnya bagi masyarakatnya serta kesempatan-kesempatan yang diberikan oleh masyarakat kepadanya. Pentingnya peran ia dapat mengatur perilaku seseorang[2]. 
Peran tokoh masyarakat dalam membina toleransi antarumat beragama yaitu sebagai pembimbing dan sebagai mediator. Menurut Natawidjaja [3]bimbingnadalah proses pemberian bantuan kepada masyarakat yang dilakukan secaraterus-menerus, supaya masyarakat tersebut dapat memahami dirinya, sehingga sanggup mengarahkan dirinya, dan dapat bertindak secara wajar, sesuai dengan lingkungannya.

Sedangkan mediasi adalah suatu proses penyeleseaian permasalahan antardua pihaka tau lebih melalui perundingan atau cara mufakat dengan bantuan pihak netral yang tidak memiliki kewenangan memutus[4].

\section{Tinjauan Tentang Toleransi Antarumat Beragama}

a. Pengertian Toleransi

Toleransi adalah sikap yang harus dikembangkan di dalam masyarakat sipil (civil society) dengan cara saling menghargai dan menghormati segala aktivitas yang dilakukan oleh pribadi atau sebuah kelompok dalam masyarakat[5].

Pengertian toleransi menurut Nurcholish Madjid, toleransi merupakan persoalan ajaran dan kewajiban melaksanakan ajaran itu. Untuk menjaga dan memelihara toleransi diperlukan sikap menghargai orang lain sebagai masyarakat dalam menghargai hak asasi manusia sebagai umat beragama[5].

b. Toleransi Antarumat Beragama.

Sebagai umat beragama yang tinggal di lingkungan yang beragam, sudah sepatutnya kita memiliki sikap saling menghargai, menghormati, dan memberikan kebebasan kepada orang lain yang memiliki perbedaan agama, psikologi, nasionalis, ras, suku, dan lain sebagainya yang berbeda dengan diri sendiri, serta tidak mengganggu segala aktifitas yang berhubungan dengan kegiatan keagamaannya baik itu perseorangan maupun sekelompok masyarakat.

Beberapa ciri-ciri toleransi menurut Umar Hasyim [7]sebagaiberikut

1) Mengakui Hak Setiap Orang

Setiap manusia tentunya mempunyai hak yang berbeda dalam kehidupnya. Mengakui hak setiap orang merupakan suatu sikap mental yang mengakui bahwa setiap manusia berhak untuk menentukan sikap laku dan nasipnya sendiri.

2) Menghormati Keyakinan Orang Lain

Semua orang memiliki keyakinan yang berbeda-beda, terlebih hal agama. Tidak menghormati keyakinan orang lain atau memaksa keyakinan seseorang dengan cara kekerasan atau dengan cara yang tidak baik akan mengakibatkan orang lain bersikap hiprokit atau munafik.

3) Agree In Disagreement (Setuju Dalam Perbedaan)

Setiap manusia itu berbeda. Perbedaan tidak harus menimbulkan pertentangan karena perbedaan selalu ada di dunia ini.

4) Saling Mengerti

Tidak akan terjadi saling menghormati apabila tidak ada rasa saling mengerti dan bila ada rasa tidak suka bahkan membenci ini adalah salah satua kibat dari tidak adanya saling mengerti dan saling menghargai satu dengan yang lainnya.

5) Kesadaran Dan Kejujuran

Sikap toleransi menyangkut sikap dan kesadaran bakti seseorang dan kesadaran jiwa menimbulkan kejujuran dan kepolosan sikap laku.

Jadi, toleransi antarumat beragama adalah hubungan yang harmonis diselimuti rasa aman dan damai antarumat beragama yang tinggal dalam satu wilayah di mana 
masyarakatnya memiliki sifat saling mengerti, menghargai, dan menghormati hak-hak setiap mayarakat yang berbeda dengan dirinya meskipun itu bertolak belakang dengan dirinya dan tumbuh sikap toleransi yang menyangkut kesadaran bakti seseorang dan kesadaran jiwa yang menimbulkan kejujuran dan kepolosan sikap laku dalam bermasyarakat.

\section{METODE PENELITIAN}

\section{Metode Penelitian}

Metode penelitian kualitatif adalah metode penelitian yang digunakan untuk meneliti pada kondisi objek yang tidak direkayasa sesuai dengan pendekatan deskritif. Peneliti sebagai instrumen kunci, teknik pengumpulan data dilakukan secara trianggulasi (gabungan), pada penelitian ini peneliti hanya mengamati fenomena yang dialami oleh subjek dan informan penelitian seperti perilaku, motivasi, tindakan secarautuh, lengkap dan representatif(mewaakili)[8]. Dalam penelitian ini hanya meneliti bagaimana peran dari tokoh masyarakat dalam memberikan binaan toleransi antarumat beragama di masyarakat.

\section{Tempat dan Waktu Penelitian \\ a.Tempat Penelitian}

Tempat penelitian di Kelurahan Karang Baru Kota Mataram, namun dalam penelitian ini peneliti hanya memfokuskan penelitian pada dua lingkungan yaitu Lingkungan Karang Baru Utara dan Lingkungan Karang Baru Selatan.

\section{b. Waktu Penelitian}

Peneliti mulai mengadakan penelitian pada tanggal 25 April 2021 sampai 25 Juni 2021.

\section{c. Subjek dan Informan Penelitian}

\section{1). Subjek Penelitian}

Subjek penelitian merupakan pihak yang akan diteliti. Subjek penelitian merupakan pusat perhatian dalam penelitian[9]. Yang menjadi subjek pada penelitian ini adalah tokoh masyarakat.

\section{2). Informan Penelitian}

Informan penelitian adalah seorang pembicara asli yang memberikan informasi tentang masalah yang diteliti sebagai sumber informasi[10]. Informan penelitian ditentukan dengan menggukan teknik purposive sampling, yaitu suatu teknik pengambilan sampel dengan menggunakan pertimbangan tertentu[8]. Sehingga yang termasuk informan dalam penelitian ini antara lain

Lembaga, Organisasi Keagamaan, dan masyarakat Lingkungan Karang Baru Utara dan Lingkungan Karang Baru Selatan

\section{d. Teknik Pengumpulan Data}

Teknik pengumpulan data dilakukan dengan tiga cara. Pertama, melalui wawancara. Menurut Esterberg[8] wawancara adalah pertemuan dua orang untuk bertukar informasi dan ide melalui tanyajawab. Kedua, Observasi. Menurut Nasution[8] menyatakan bahwa observasi adalah dasar semua ilmu pengetahuan. Peneliti hanya dapat bekerja berdasarkan data, yaitu fakta mengenai dunia kenyataan yang diperoleh melalui observasi. KetigaDokumentasimerupakancatatanperistiwa yang sudahberlalu. Dokumenbisaberbentuk tulisan, gambar, atau karya-karya monumental dari seseorang[8].

\section{e. Teknik Analisis Data}

Dalam penelitian ini, teknik analisis data yang digunakan adalah analisis kualitatif. Langkah analisis data ini mengacu pada Miles dan Huberman [8] yang terdiri dari pengumpulan data, reduksi data, penyajian data, dan verification. 
Dalam teknik analisis data, tidak terlepas dari trianggulasi[8]. Adapun trianggulasi sebagai berikut

(1). Trianggulasi Sumber, untuk menguji kredibilitas data dilakukan dengan cara mengecek data yang telah diperoleh melalui beberapa sumber.

(2). Trianggulasi Teknik, untuk menguji kredibilitas data dilakukan dengan cara mengecek data kepada sumber yang sama dengan teknik yang berbeda.

(3). Trianggulasi Waktu, sering mempengaruhi kreadibilitas data. Data yang dikumpulkan dengan teknik wawancara di pagi hari pada saat narasumber masih segar, belum banyak masalah, akan memberikan data yang lebih valid sehingga lebih kredibel.

\section{HASIL DAN PEMBAHASAN}

\section{Hasil Penelitian}

Dari hasil penelitian, bahwa peran tokoh masyarakat sudah berjalan sesuai dengan kedudukan mereka. Dalam membina toleransi antarumat beragama tokoh masyarakat berperan sebagai pembimbing dan sebagai mediator.

a. Peran sebagai pembimbing, tokoh masyarakat memberikan bimbingannya dalam kegiatan keagamaan antara lain:

\section{1). Ceramah pada saat pengajian;}

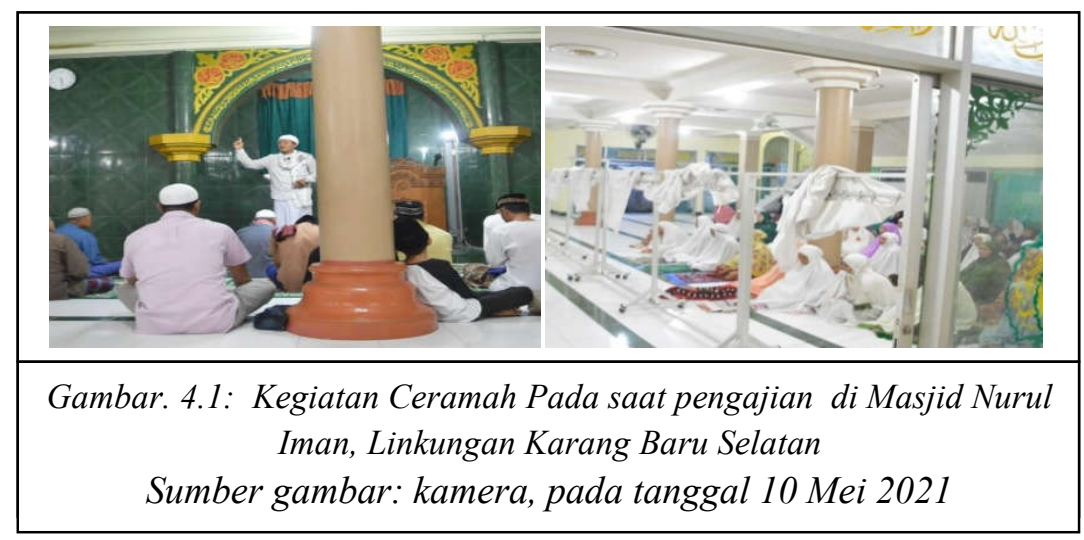

Peran bimbingan yang diberikan oleh tokoh agama Islam yaitu Kiyai Kamarudin melalui ceramah pada saat pengajian di Masjid Nurul Iman, Lingkungan Karang Baru Selatan. Pengajian ini dilaksanakan pada hari Senin malam tanggal 10 Mei 2021 pukul 20.00 WITA atau setelah Sholat Isyak, yang diawali dengan pembacaan Sholawat, selanjutnya dibuka dengan pembacaan surat Al-Fatihah, dilanjut pembacaan Asmaul Husna, masuk ke acara inti yaitu ceramah yang dipimpin oleh Kiyai Kamarudin, dan ditutup dengan doa penutup.

\section{2). Renungan Doa Mingguan}

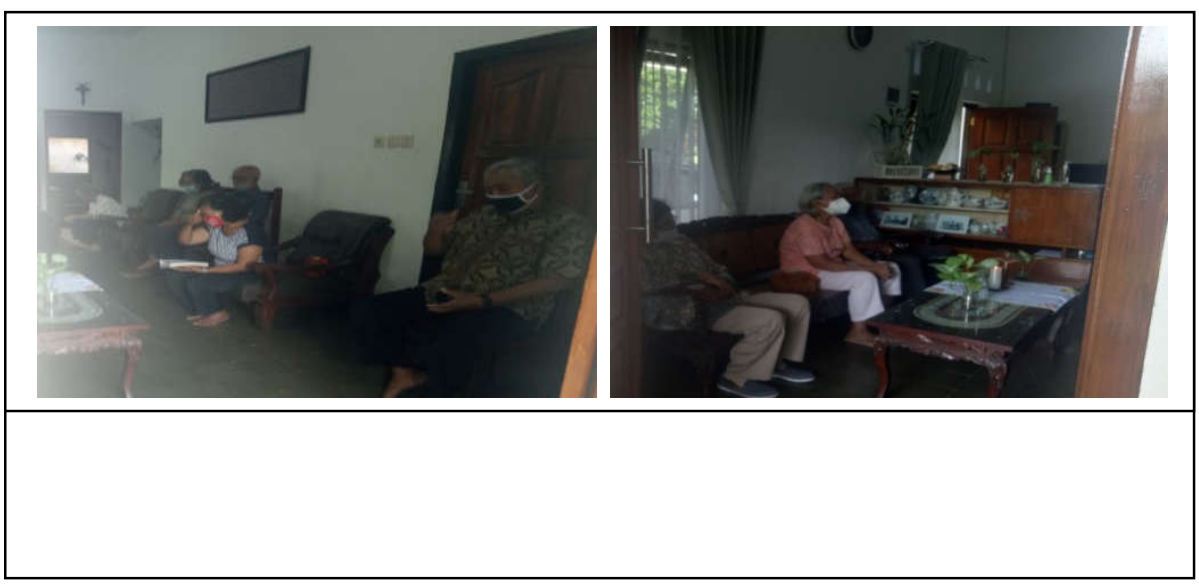



tanggal 12 Mei 2021, pukul 08.30 WITA, bertempat di rumah bapak Paulus Harry Hadi, beliau merupakan warga Komunitas Basis Gerejawi (KBG) Santo Yohanes Pembabtis Rembiga. Kegiatan dibuka dengan lagu Rohani dan dilanjutkan doa pembuka, pemimpin doa menyapa umat dan membacakan tema bacaan yang sesuai dengan bacaan Injil hari itu, pemimpin doa membacakan bacaan Injil dan umat mendengarkan, pemimpin doa mengajak umat untuk menghayati kembali isi bacaan Injil yang dibacakan, selanjutnya umat diminta untuk sharing atau membagikan pengalaman hidup mereka yang mungkin diantara umat ada yang memiliki cerita hidup seperti bacaan Injil yang dibacakan, setelah beberapa umat sharing pimimpin doa menyampaikan renungan singkat dari bacaan Injil, selanjutnya ditutup dengan doa penutup yang diakhiri dengan satu kali doa Bapa Kami dan tiga kali doa Salam Maria.

\section{3). Dharma Wacana(ceramah)}

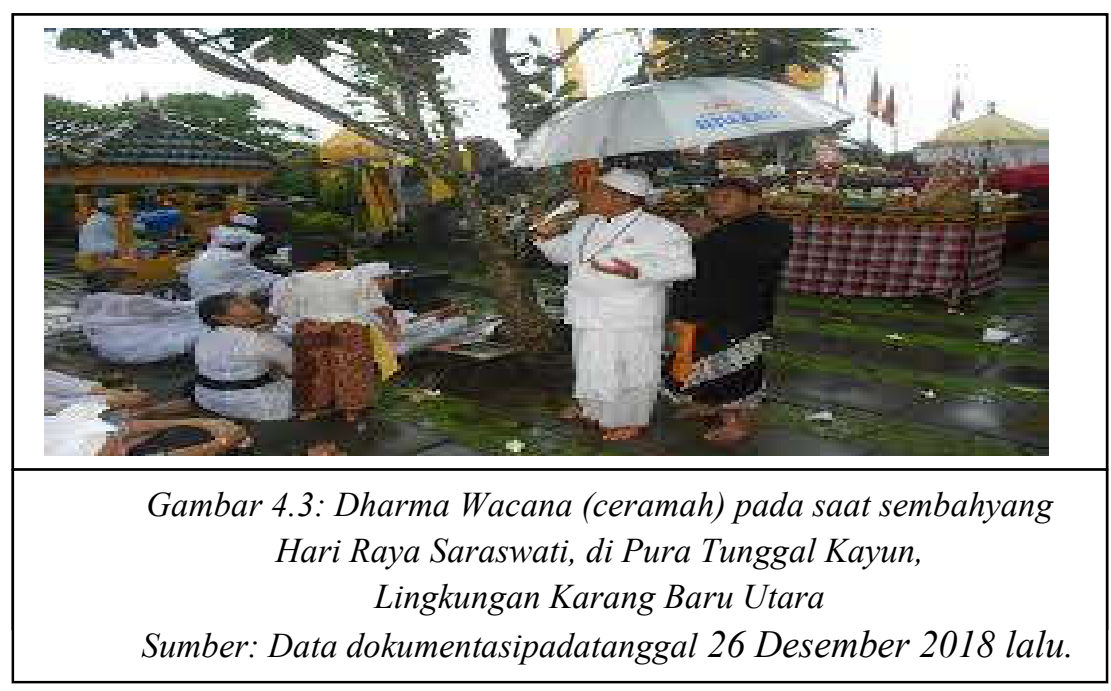

Dharma Wacana (ceramah) adalah salah satu rangkaian acara dalam kegiatan persembahyangan umat Hindu di samping ritual persembahyangan lainnya yang diadakan pada saat sembahyang hari raya di Pura, seperti sembahyangan Hari Raya Galungan, Kuningan, Nyepi, Saraswati, Odalan(ulangtahun Banjar atau Pura) dan hari raya agama Hindu lainnya. Persembahyangan dilaksanakan oleh masing-masing pengurus Pura. Acara persembahyangan biasanya dibuka oleh pembawa acara, dilanjutkan dengan ritual ngayab banten (mengaturkan sesajen) oleh Panindita (Pemangku) yang diiringi dengan lantunan kidung-kidung suci bernuasa Bali, setelah ngayanb banten (mengaturkan sajen) dilanjutkan Dharma Wacana(ceramah) kurang lebih 30 menit tergantung dari topik yang dibawakan.

b. Peran sebagai mediator, tokoh masyarakat lain seperti Ketua Rukun Tetangga (RT) dan Kepala Lingkungan juga berperan sebagai mediator apa bila terjadi kesalah pahaman antarmasyarakat atau permasalahan yang ada di masyarakat guna terbinanya toleransi antarumat beragama. 
Seperti yang pernah terjadi beberapa tahun silam, kasus kecelakaan lalulintas antara salah satu warga dari Lingkungan Karang Baru Utara dengan warga Lingkungan Karang Baru Selatan. Waktu itu, seorang pemuda dari warga Karang Baru Utara yang mengendarai sepeda motor menabrak seorang ibu warga Karang Baru Selatan yang menyeberang jalan.

Kasus ini kemudian diselesaikan secara musyawarah untuk mendamaikan kedua kelompok warga yang terlibat kecelakaan. Sebab bila hal ini tidak segera dimediasi, permasalahan akan berlarut-larut dan merambat kelini lainnya, termasuk kehubungan antarumat beragama.

\section{Pembahasan}

Pada kegiatan keagamaan sebagai bimbingan bagi masyarakat, tokoh masyarakat mengambil materi bimbingannya sesuai dengan ajaran dari masing-masing agama. Dalam ajaran Agama Islam toleransi tertera dalam surat-surat yang ada di Al-Quran seperti pada surat Qs. AlKafirunayat 6 yang bunyiarinya: "Bagimu agamamu dan bagiku agamaku”. Sebagaiumat Muslim hendaknya tidak boleh mengganggu, bahkan mencampuri aktivitas keagamaan orang lain namun sebaliknya, bersikap menghargai dan menghormati kelompok masyarakat yang beragama lain. Selain itu dalam surat Qs. Al-Baqarah ayat 256, yang bunyiartinya: "Tidak ada paksaan dalam beragama". Subtansi dari toleransi adalah keikhlasan dalam beragama tanpa ada paksaan dan campur tangan orang lain. Penjelasan dari dua surat ini sesuai dengan pendapat seorang tokoh Nasionalis agamis, Bapak Prof. Muhammad Quraish Shihab, yang di mana Sebagai seorang Muslim haruslah bersikap baik terhadap orang lain (non-Muslim) dengan tidak mencemooh atau menyalahkan keyakinannya. Selain itu, sebagai umat Muslim hendaknya tidak memaksakan keyakinannya kepada orang lain.

Bagi Agama Katolik, ajaran cinta kasih merupakan subtansi dari toleransi antarumat beragama. Dalam Injil Lukas bab 1 ayat 27b tertulis "kasihilah sesamamu manusia seperti dirimu sendiri”. Sebagai wujud kasih, tertera dalam bacaan lengkap pada Injil Lukas bab 10 ayat 25-37 tentang perwujudan dan tindakan nyata menolong sesama manusia tanpa memandang status sosial, agama, dan suku. Cinta kasih juga merupakan perintah dari Yesus Kristus (Tuhan Yang Maha Esa) tertera dalam Injil Yohanes bab 15 ayat 17 yaitu "Inilah perintahKu kepada mu: Kasihilah seorang akan yang lain". Jadi toleransi dalam pandangan agama Katolik lebih menekankan ajaran cinta kasih kepada semua orang tanpa memandang status sosial, ras, suku, bahkan agama orang lain atau bisa dikatakan ajaran agama Katolik memandang semua orang itu sama.

Toleransi dalam agama Hindu tidak terlepas dari konsep Tri Hita Karana. Konsepdari Tri Hita Karana antara lain: hubungan manusia dengan Tuhan, hubungan manusia dengan manusia, dan hubungan manusia dengan alam. Ketiganya saling berkaitan satu sama lain. Toleransi antarumat beragama terletak pada hubungan manusia dengan manusia yaitu hendaklah sesama manusia saling menghargai, menghormati, tidak memiliki pemikiran yang negatif (rasa curiga) dan bersikap adil satu sama lain. Tidak hanya itu, toleransi juga tercipta bila menjauhkan diri dari sikap-sikap intoleransi yang berdasarkan agama, ras, warna kulit, bahasa, derajat, tradisi dan lain sebagainya. Bahkan, Tuhan selalu menerima semua manusia walaupun, manusia beribadah kepadanya melalui berbagai jalan yang berbeda-beda. Sesuai dengan bunyi dalam Kitab Suci Bhagawad Gita IV. 11 disebutkan, artinya: Bagaimanapun (jalan) manusia mendekati-Ku, Aku terima, wahai Arjuna. Manusia mengikuti jalan-Ku pada segala jalan. Jadi dari sloka tersebut dapat dipahami bahwa Sang Hyang Widhi atau Tuhan Yang Maha Esa tidak pernah membedakan jalan atau cara manusia beribadah untuk memuja-Nya. 


\section{PENUTUP}

\section{Simpulan}

Berdasarkan hasil penelitian dan pembahasan dapat disimpulkan bahwa peranan dari tokoh masyarakat yang ada di Kelurahan Karang Baru Kota Mataram dalam membina toleransi antarumat beragama sudah berjalan sesuai dengan kedudukannya. Peran tersebut meliputi: 1.Sebagai pembimbing, yang di mana dilaksanakan oleh tokoh agama kepada masyarakat sesuai dengan ajaran agama masing-masing yaitu: a. Ceramah pada saat kegiatan Pengajian bagi umat Muslim, b. Renungan pada kegiatan Doa Mingguan bagiumat Katolik dan c. Dharma Wacana(ceramah) pada saat sembahyangan hariraya di Pura bagi umat Hindu. 2.Sebagai mediator yaitu membantu penyelesaian suatu permasalahan di masyarakat yang diberikan oleh tokoh masyarakat (Ketua RT dan Kepala Lingkungan) agar permasalahan tersebut tidak berlarutlarut dan dapat diselesaikan secara kekeluargaan.

\section{Saran}

a. Bagi pemerintah pusat maupun pemerintah daerah khususnya Pemerintah Nusa Tenggara Barat mampu membuat sebuah peraturan yang nantinya dapat berguna sebagai pedoman untuk melindungi masyarakat sehingga dapat mengupayakan kehidupan bermasyarakat yang kondusif di dalam keberagaman agama.

b. Bagi Masyarakat Kelurahan Karang Baru Kota Mataram untuk tetap aktif dalam mengikuti kegiatan keagamaan yang diadakan oleh tokoh masyarakat demi mengupayakan terbinanya hidup bertoleransi antarumat beragama, menghargai perbedaan yang ada, tidak bersikap eksklusif atau tertutup melainkan inklusif atau bersifat terbuka.

c. Bagi peneliti berikutnya yang tertarik dengan judul skripsi ini dapat digunakan sebagai landasan dan referensi dalam melakukan penelitian serta dapat melakukan penelitian melalui sudut pandang yang berbeda.

\section{DAFTAR PUSTAKA}

[1] D. Sudiadi, "4251-EN-menuju-kehidupan-harmonis-dalam-masyarakat-yang-majemuk-suatupandangan-pentingn.pdf," Kriminologi Indones., vol. 5, pp. 33-42, 2009.

[2] B. Soekanto, Sosiologi Suatu Pengantar, 48th ed. Jakarta: PT RAJAGRAFINDO PERSADA, 2017.

[3] L. Satriah, "Bimbingan dan Konseling Kelompok Seting Masyarakat," L. . D. Satriah, Ed. FOKUSMEDIA, 2016, p. 13.

[4] T. Rahmadi, Mediasi Penyelesaian Sengketa Melalui Pendekatan Mufakat, 2nd ed. Depok, 2011.

[5] Rohidin, Konstruksi Baru Kebebasan Beragama Menghadirkan Nilai Kemanusiaan yang Adil dan Beradap di Negara Hukum Indonesia, Pertama. Yogyakarta: FH UII Press, 2015.

[6] A. Pratama and D. T., Azizah Husin, "Partisipasi Tokoh Masyarakat dalam Kewaspadaan Penyalahgunaan Narkotika di Kelurahan Timbangan Kabupaten Ogan Ilir," J. Nonform. Educ. Community Empower., vol. Volume 2 (, pp. 82-91, 2018.

[7] U. Hasyim, Toleransi dan Kemerdekaan Beragama Dalam Islam Sebagai DasarMenuju Dialog dan Kerukunan Antar Agama. Surabaya: Bina Ilmu, 1979. 
p-ISSN : 2655-7304

e-ISSN : 6655-8953

[8] Prof. Dr. Sugiono, Metode Penelitian Kuantitatif Kualitatif dan R\&D, 2nd ed. Bandung: Alfabeta, 2019.

[9] S. Arikunto, Prosedur Penelitian Suatu Pendekatan Praktik (Edsisi Revisi), 6th ed. Jakarta: Renika Cipta, 2010.

[10] Prof.Dr.Sugiono, Metode Penelitian Pendidikan Pendekatan Kualitatif, Kuantitatif, danR\&D, 4th ed. Bandung: CV Alfabeta, 2013. 